\title{
Teaching Reading Comprehension By Using Pictures
}

\author{
Aulia Azmi ${ }^{1}$ \\ \{auliaazmi2591@yahoo.co.id\} \\ ${ }^{1}$ Universitas Sari Mulia, Banjarmasin, Indonesia
}

\begin{abstract}
Reading is very important skill in the education field, students need to be exercised and trained in order to have a good reading skill. Unfortunately, mostly students are still have difficulties to master the sub skills of reading such as finding general picture, finding main idea and finding specific information. Then, to solve that problem, media can be used such as pictures which also can create enjoyable classroom, therefore can make students motivated to study.

Using pictures especially individual picture and picture series in this study also proposed to help the students improve their reading achievement. This study uses quasi-experimental design which the samples are divided into experimental class (IXA) and control class (IXB). The data needed of this study are collected from pre-test and post-test. The findings from the post test of the experimental and control class indicate that using pictures is significantly effective in improving students' reading comprehension. It can be seen from experimental class pre-test and post-test averages are 42.50 and 75.45 , while the control class only gets 50 for pre-test and 69.77 for post-test. Moreover, the t-test 2.08 is higher than t-table (1.68).

In conclusion, the experimental class improves better than control class.
\end{abstract}

Keywords: Reading comprehension, achievement, pictures

\section{Introduction}

English is an international language which is spoken by many people around the world, either as first language, second language or a foreign language. There are four language skills that we must learn when we are learning English, they are: listening, speaking, reading, and writing. Reading skill is very important in the education aspect. There are many reasons why getting students to read English text is an important part of the teacher's job. In the first place, many of them want to be able to read text in English either for their careers, for study purposes or simply for pleasure [1]. Moreover, comprehension is cannot be separated with reading itself. Because without comprehend or understand the text or what the text is about, the activity of reading is useless.

In SMPN 1 Gambut, based on the researcher' interview with the English teacher in pre research, it is found that there are problems in teaching reading comprehension. The problems in teaching reading comprehension mostly are founded at ninth grade students, because in that grade the students learning some reading assignment in the last level at Junior High School and the reading assignment certainly is more difficult compared with seventh grade and eight grade before. Moreover, the researcher gift a test in reading comprehension as a proof to make sure really there are problems in reading comprehension at ninth grade students. Therefore, after doing the test, it is found out that there are problems in teaching reading comprehension especially in the sub skills of reading at ninth grade students.

In teaching and learning process, researcher also found based on interview that the teacher is confused in choosing appropriate media of teaching reading comprehension. And also, In pre research, researcher observed teaching reading comprehension process. The researcher found that English teacher still uses conventional treatment. Consequently, the students seem like feel boring in the class room. Media is various kinds of component in students' environment which can give stimulate to study[2]. One of alternate media is using pictures in teaching process.

In this research, pictures that are used only individual picture and picture series. Individual picture is suitable for teaching report text to describe the object which is told in the text and picture 
series is suitable for teaching procedure text to show the steps for doing something by series of picture. Therefore, students can comprehend the text through seeing the individual picture in the form of puzzle pictures to learn report text and also picture series to learn procedure text then relate both of pictures to the text hopefully the students who have difficulty in reading comprehension can improve their ability in reading comprehension. In conclusion, based on the explanations above, the researcher is interested in conducting a research using pictures in teaching reading comprehension. Moreover, the research problem in this research is "Is there any significance difference in students' achievement between students who are teaching by using individual picture and picture series and students' who are teaching without using individual picture and picture series in reading comprehension?".

\section{Literature Review}

\subsection{Reading}

Reading is more than interaction between a reader and a text [3]. It means that reading has any interaction, it can be interaction between a reader and a text, between a reader and the writer of the text and also between a reader and a social context where reading's activity is happened. Then, reading as interactive process between a reader and the text which leads to automaticity or reading fluency [4], It means that reading is a process which the reader interacts dynamically with the text as he or she tries to understand the meaning from it and where various kind of knowledge are being used.

In English, reading is one of the skills in learning which can be classified into two types: initial reading and reading comprehension. Initial reading is an effort made by those who have not been able to read to learn reading (e.g., how to read the alphabets and combination of letters or simple words). Meanwhile, reading comprehension is an activity aimed to understand the messages of particular text [5]. Another definition is based on Johnston's opinion [3] reading comprehension is a complex behavior which involves conscious and unconscious use of various strategies, including problem solving strategies, to build the model of meaning which the writer is assumed to have intended. Based on the definition above, it can be concluded that reading comprehension is an activity in reading which the aim is to understand the meaning of text or what the writer's intention is through some strategies; the following are:

1. Scanning

Scanning is to identity particular information in a text. Information can be contained in particular words, phrases, or even sentences [6]. The learner must be learns how to get such information and it is a duty of an English teaching skills.

2. Skimming

The term of skimming is used to denote the method of glancing through a text quickly in order to get overall gist of the text. This is usually done through doing the so called progressive reading.

3. Summarizing

The key to working with a student with reading difficulties is starting small. If your reading students are reading a picture book, ask them to read one page and then summarize it. Teach struggling readers that to summarize means to tell the important parts of a story, page, or sentence in chronological order.

4. Visualization

Many struggling readers, who have comprehension problems, do not create pictures in their own heads when they read. They are concentrating many more on reading the words that they are not creating the pictures to go with them. First slow down the reader, tell them to take a breath at commas and periods, and think about what they are reading. When the first practicing visualization, we may ask students to illustrate what they think is going on in the story and what they see, Model this strategy for students.

Moreover, there are three sub skills of reading:

1. Finding general picture: similar as recognizing the topic or title of the text. 
2. Finding main ideas: a main idea sentence is the most general statement the author makes about the topic or subject of the paragraph [5]. The author usually states main idea in the first sentence of paragraph. However it can also stated in the middle, at the end or leaves it unstated in implied meaning.

3. Finding specific information: similar as scanning skill. Scanning is a high-speed reading skill used for locating specific information [3].

\subsection{Using Pictures as media in Teaching Reading Comprehension}

Media is very useful in teaching and learning process because through using media can make student interest in studying and also motivate the students. Media is various kinds of component in students' environment which can give stimulate to study. Besides, all physical equipment can provides message and also give stimulate students to study, can be called as media [2]. Based on the definition of media before, it can be concluded that media is a tools in teaching and learning process which is the aim is to rising students' interest to study.

One of familiar media in teaching and learning process is pictures. Pictures are the most widely available of all teaching materials. Pictures can be found in newspapers, magazines, old text books, catalogues, brochures, calendars, internet etc. In this research, researcher is using pictures such as individual picture and picture series as media in teaching reading comprehension at ninth grade students of SMPN 1 Gambut in academic year 2013/2014. Individual picture is using for teaching reading about report text, because as the meaning of individual picture itself, this picture can describe the object which is told in the report text. Meanwhile, picture series is used in teaching reading about procedure text, because the function of picture series is to tell a story or sequence of events, hence this picture can describe or tell sequence of step about how the way to do something in procedure text.

There are some procedure in using pictures such as individual picture and picture series in teaching reading comprehension, the following are:

1. The steps of using individual picture in teaching reading comprehension, especially in teaching report text in this research:

- $\quad$ Teacher explains about report text.

- Then, ask students to make a pairs.

- Teacher distributes puzzle of pictures to each pairs.

- $\quad$ Students in pair rearrange puzzle picture into complete picture.

- Students match which one the text that is matching and describe the picture.

2. The steps of using picture series in teaching reading comprehension, especially in teaching procedure text in this research:

- Teacher explains about procedure text

- Then, ask students to make a pairs.

- Teacher distributes series of pictures to each pairs and the example of procedure text.

- Students in pairs organize pictures into correct order, based on the example of procedure text which distributed by the teacher before.

Individual picture and picture series are classified as part of pictures or pictorial material has many benefits for teaching. There are four functions in teaching through visual media which can give input or advantages for teaching reading[7]. The following are:

1. Function of attention: visual media can make students give their attentions to concentrate to the material that is related with the meaning of visualization of the media that is showed or also the text on subject.

2. Function of affective: visual media can improve student interest in studying and when they read a text with picture. Picture and symbol of visualization can touch student's emotional and behavior.

3. Function of cognitive: based on research show that through visual media can get the goal fluently to comprehend and remember information or messages that are contained in picture.

4. Compensatory function: based on research show that visual media which gives context to comprehend the text can help the students who are low in reading ability to organize 
information in the text and remember it again. In other hand, visual media function to accommodate the students who are low and low to get and comprehend the subject that is form of text or verbalize.

\section{Research Method}

\subsection{Research Design}

The research design that the researcher used was experimental research specifically, quasiexperimental research design. There are three kind of quasi experimental designs are the matchingonly design, counterbalance design, and time-series design [8.] Then the matching only design is divided again into two kinds are the Matching-only Posttest-only Control Group Design and the Matching only Pretest-Posttest Control Group Design. In this research, the researcher decided to use the Matching-only Pretest-Posttest Control Group Design. In quasi-experimental design, there should be at least one experiment group and one control group. In this case, the experimental group is taught by using pictures and control group is taught without using pictures. After that, the experimental groups and control group are given pretest and posttest to examine their reading achievement. Moreover, quantitative approach also used to describe the data which have collected. quantitative approach is an approach to find out a knowledge which using numeral data as a tool to find statement about what we want to know.

\subsection{Sampling Technique}

\subsubsection{Population}

Population is the group of interest to the researcher, the group to whom the researcher would like to generalize the result of the study[8]. Moreover, the population of interest is usually a group of persons who posses certain characteristics. Therefore, the population of this research is the ninth grade students of SMPN 1 Gambut which there are six classes: IX A, IX B, IX C, IX D, IX E, and IX F which total of the students are 141 students.

\subsubsection{Sample}

A sample in research study is the group on which information is obtained [8]. In this research, the data from students are taken by Purposive Sampling Technique which is done by taking subject based on certain purpose. The researcher uses this technique by considering that the two classes are taught by the same teacher and same total of the students include 22 students in IX A and 22 students in IX B and also have more or less similar ability. Before conducted this research, researcher did pre research and interview the English teacher. Then she said that IX A and IX B have more or less similar ability. Therefore, to make sure both of class that the students have similar ability, a test is given.

\subsection{Research Procedures}

In this research, the researcher used test to collect the data. Achievement test is used to measure an individual's knowledge or skill in a given area or subject[8]. In this research, the test is given before the treatment (pre-test) to know the students' prior knowledge in reading comprehension and after the treatment (post-test) to know students' achievement in reading comprehension after treatment. The test type is used multiple choice contain 10 questions in report text and 10 question in procedure text, totally 20 questions which each number got 5 score. This test is divided into three sub-skills; these sub-skills are general picture, main idea and specific information to both of report text and procedure text.

\subsection{Technique of Data Analysis}

In this research, the researcher used some steps to analyzing the data which is collected, the following are:

1. Analyzing the test is done through some steps as follow:

a. Doing pretest and then posttest to the samples. 
b. Counting and interpreting students' pretest and posttest scores by using the following formula : Score $=\frac{\text { right answer }}{\text { total items }} \times 100$

Then, the researcher interpreted the score into the table according to standard score in SMPN 1 GAMBUT.

Table 1. Standard Score Interpretation in SMPN 1 Gambut

Score
Interpretation

\begin{tabular}{ll}
\hline $\mathbf{9 0}-\mathbf{1 0 0}$ & Excellent \\
$\mathbf{8 0}-\mathbf{8 9}$ & Good \\
$\mathbf{7 0}-\mathbf{7 9}$ & Fair \\
$\mathbf{- 7 0}$ & Fail
\end{tabular}

Note:

1) Excellent if it reaches a value between 90 to 100 points.

2) Good if the reaches value of between 80 until with 89.

3) Fair if the reaches value of between 70 until with 79 .

4) if the test value is less than 70.

c. The researcher analyzes the data using t-test.

The quasi experimental design with pre-test and post-test is analyzed by using t test as the following:

1) Standard Deviation's Formula [9]

$S^{2}=\frac{\left(n_{1}-1\right) S_{1}^{2}+\left(n_{2}-1\right) S_{2}^{2}}{n_{1}+n_{2}-2}$

T-test Formula

$\mathrm{t}=\frac{x_{1}-x_{2}}{\sqrt[s]{\frac{1}{n_{1}}+\frac{1}{n_{2}}}}$

Where :

$x_{1}=$ mean of experiment class

$x_{2}=$ mean of control class

$n_{1}=$ subject of the experimental class

$n_{2}=$ subject of the control class

$S_{1}^{2}=$ variance of the experimental class

$S_{2}^{2}=$ variance of the control class

\section{Data Analysis and Results}




\subsection{The Description of Students' achievement \\ 4.1.1. Experimental Class}

Based on the pre-test which was held on $3^{\text {rd }}$ September 2013, the result of students' average score was 42.50 . Then the result of post-test which was held on $8^{\text {th }}$ October 2013 was 75.45 . It means, the students' average score increased 32.95, in other word experimental class had an improvement in reading comprehension. The improvement from pre-test to post test in experimental class was really higher. In both pre-test and post-tests, there was no one student that got excellence score in pre-test, meanwhile 2 students got excellence score in post-test. Then, there was only one student got good score in pre-test while 5 students in post-test. Next, there were 12 students got fair score in post-test when there was only one student got fair score in pre-test. Moreover, the higher improvement was shown from the students that were got fail score. In pretest, there were 20 students failed, but in post-test there were only 3 students failed.

\subsubsection{Control class}

Based on the result of pre-test on $4^{\text {th }}$ September 2013 the students' average score was 50 and post-test on $9^{\text {th }}$ October, it was 69.77 . From the result, it can be seen the average score has already increased up to 19.77. The control class also shows the improvement in reading comprehension, but the improvement is not as significant as the experimental class. The improvement from pre-test to post test in control class was lower than experimental class. None student got the excellence score in pre-test, meanwhile in post-test there were only one student got it. Then, there were one student got the good score in pre-test while 3 students got this score in post-test. Moreover, there were 3 students got the fair score in pre-test when in posttest there were 8 students got it. The last, there were 18 students failed in pre-test and 10 students in posttest. Thus, the improvement in the control class was not as good as in the experimental class.

\subsection{Testing Hypothesis}

In testing the hypothesis, the researcher uses t-test formula to find out how the improvement of the experimental group by comparing it with the result from control group by using the following formula:

$$
\mathrm{t}=\frac{x_{1}-\bar{x}_{2}}{\sqrt[s]{\frac{1}{n_{1}}+\frac{1}{n_{2}}}}
$$

The average score of post-test at experimental class was 75.45 with the variance $\left(S_{1}{ }^{2}\right) 59.30$. The average score of post-test at control class was 69.77 with the variance $\left(S_{2}{ }^{2}\right) 105.89$. After using the formula of $t$-test above, the researcher got the t-test $=2.08$. For significant level 0.05 and $\mathrm{df}=42$, it is got $\mathrm{t}$-table 1.68. It means that $\mathrm{t}$-test $>\mathrm{t}$-table. Therefore, Ho is rejected and Ha is accepted. In conclusion, it means that there is significant difference in students' achievement between students who are taught by using pictures and those who are taught without using pictures.

\section{Discussion and Conclusions}

The statement of the problem is to find out the significant difference in reading comprehension achievement between students who are taught by using pictures and those who are taught without using pictures at the ninth grade of SMPN 1 Gambut. Based on data obtained, below are the conclusions of this research:

a. The use of pictures in teaching reading comprehension at ninth grade students of SMPN 1 Gambut in academic year 2013/2014 has improved the students' reading comprehension especially in experimental class. It is proven by the students' score in pre-test which is 42.50 
and post-test is 75.45 which means there is improvement as 32.95 points in students' reading comprehension in experimental class. The result in control class also shows the improvement (19.77 points) in which the average score of pre-test is 50 and in post-test they got 69.77 . The control class also shows improvement in reading comprehension, but the improvement is not as significant as the experimental class.

b. Based on the calculation by using the t-test formula, the result t-test is 2.08 while t-table $(0,05) \mathrm{df}(42)$ is 1.68 . It means that the t-result is higher than t-table. It can be concluded that there is significant improvement of students' reading comprehension at experimental class than control class and $\mathrm{Ha}$ is accepted because using pictures can improve students' reading comprehension at experimental class.

c. Teaching reading comprehension by using pictures especially in this research, individual picture for teaching report text and picture series for teaching procedure text as media at ninth grade students of SMPN 1 Gambut makes students more interesting and also rises their motivation to study in teaching learning process.

\section{Suggestions}

In line with the conclusions, several suggestions are proposed as follow:

1. Since the result shows that the students in SMPN 1 Gambut have improved their score, the use of pictures such as individual picture and picture series in teaching reading comprehension can be used as one way to improve students' achievement in reading comprehension.

2. In using pictures, especially using individual picture and picture series can create more interesting classroom and rises students motivation to study. Therefore, it can be suggested to English teacher to use that media for teaching reading comprehension.

3. It is recommended to other researchers who want to conduct similar area of the researc to plan, prepare, and do the procedures of research well in order to get better result.

\section{REFERENCES}

[1] Harmer, Jeremy. How to Teach English. England: Addison Wesley Longman Limited.(1998).

[2] Sadiman, Arief S, et all. Media Pendidikan. Jakarta : PT. Raja Grafindo Perkasa.(2005).

[3] Mikulecky, Betrice S. A short course in teaching reading skills. America: Addison-Wesley Publishing Company,inc .(1990).

[4] Alyousef, Hesham Suleiman. Teaching Reading Comprehension to ESL/EFL Learner. Reading Matrix 5 (2): p.143-154.(2005).

[5] Cahyono, Bambang Yudi and Widiati, Utami.(Eds). The Teaching of English as a Foreign Language in Indonesia. Malang: State University of Malang Press. (2011).

[6] Nuttal, C. Teaching reading skills in a foreign language. London: Heinemann educational. (1982).

[7] Azhar, Arsyad. Media Pembelajaran. Jakarta : PT. Raja Grafindo Perkasa .(2005).

[8] Fraenkle, Jack and Wallen, Norman E. How to Design and Evaluate Research in Education. New York: McGraw-Hill Companies .(2006).

[9] Lestiani Handayani. Using Jigsaw in Teaching Reading Comprehension of Eight Grade Students of SMPN 3 Kandangan Academic Year 2011/2012. Banjarmasin: University of Lambung Mangkurat.(2012). 